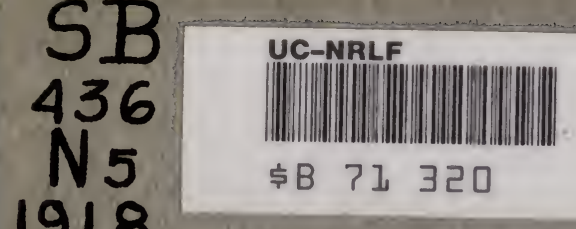

918 


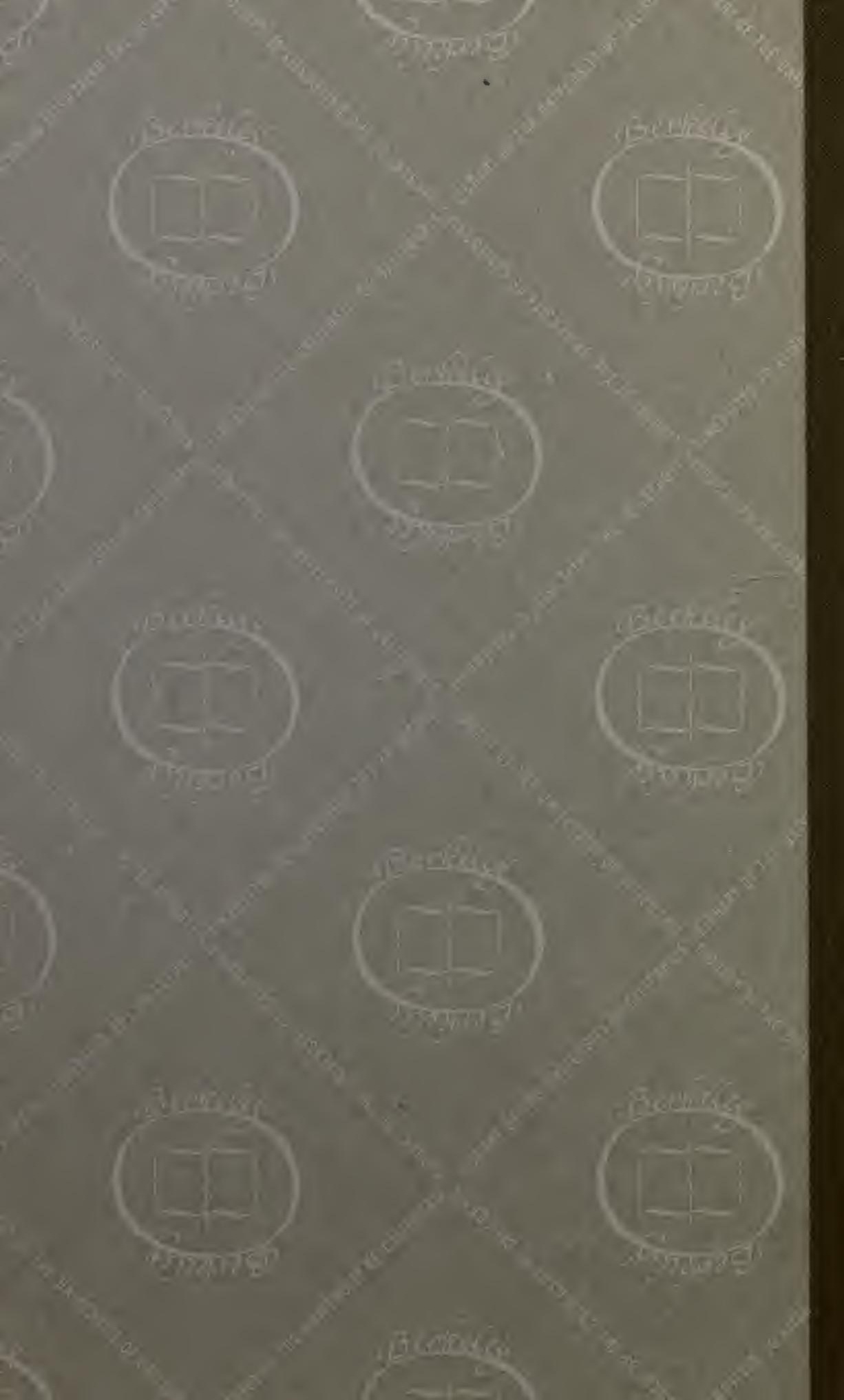






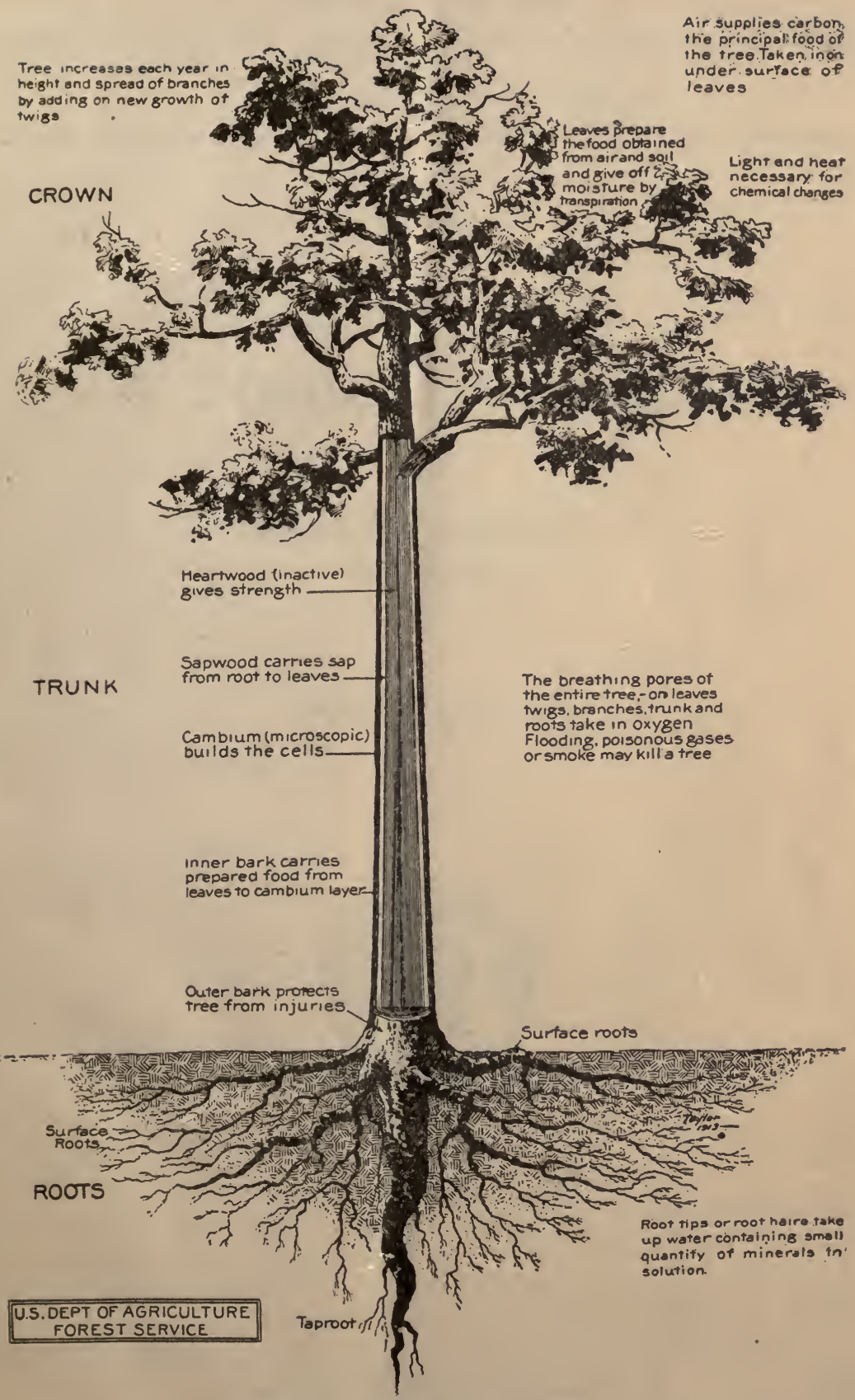

\section{HOW THE TREE GROWS}

The buas root tips ano cambium layer are the growing parts of the tree: Water containing a small quantity of minerals in solution is absorbed by the roots carrieo up through the sapwood to the leaves and there combined with carbon trom the air to make food This food is carned by the inner bark to all growing narts of the tree even down to the root-tips 



\section{A Shade Tree Guide by}

\section{ALFRED GASKILL \\ State Forester}

Published May, 1918

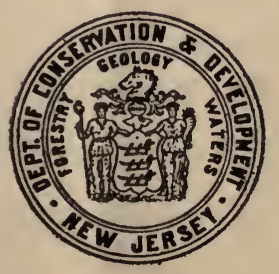

Union Hill, N. J.

HUDSON PRINTING COMPANY. 


\section{The Board of Conservation and Development}

STMON P. NORTHRUP, President,$\ldots \ldots \ldots \ldots \ldots \ldots \ldots \ldots$ Newark

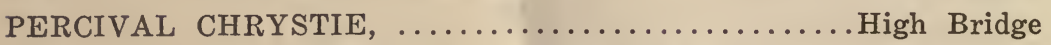

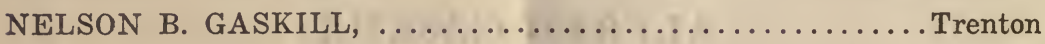
CHARLES LATHROP PACK, ................................

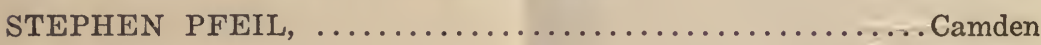

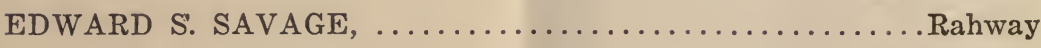

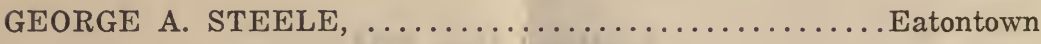

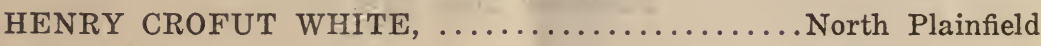

ALFRED GASKILL, Princeton, ...........State Forester and Director

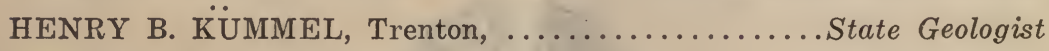
CHARLES P. WILBER, New Brunswick, ........ State Firewarden Office, State House Annex, Trenton. 


\section{6 \\ 1918}

\section{Contents.}

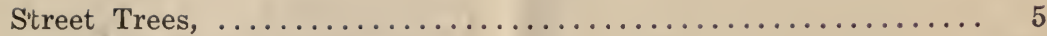

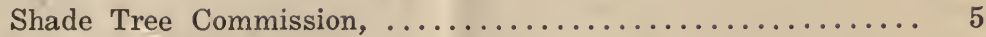

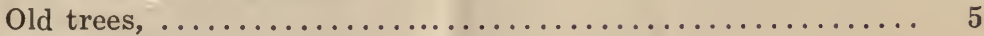

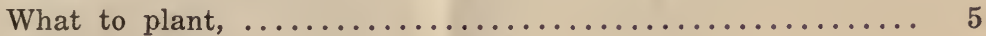

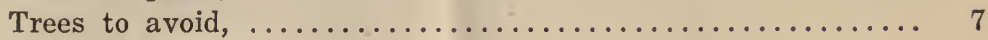

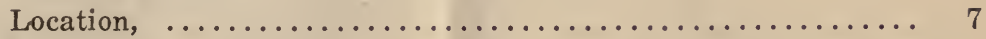

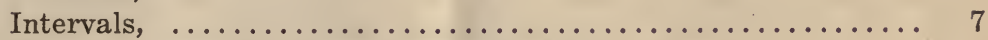

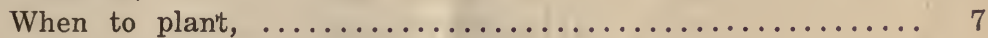

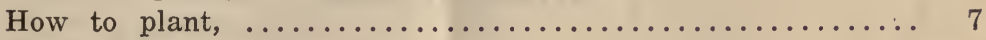

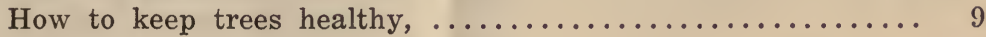

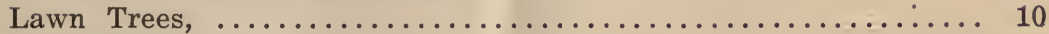

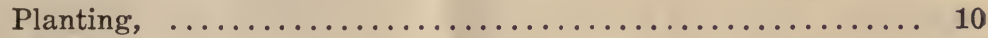

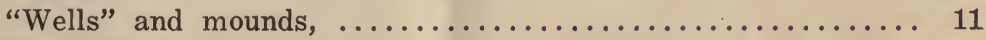

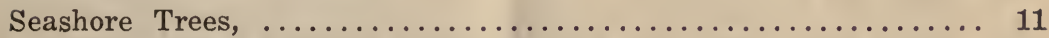

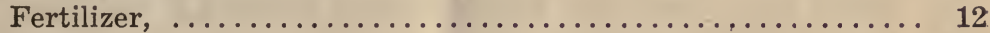

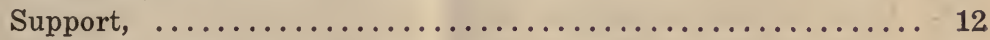

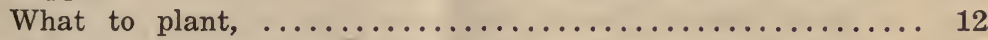

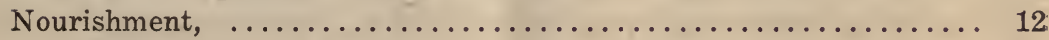

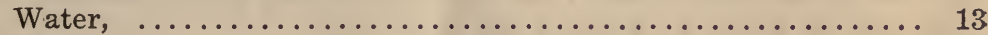

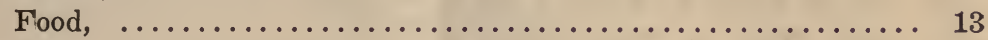

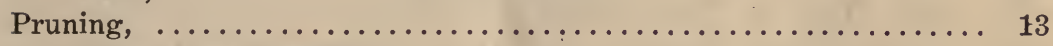

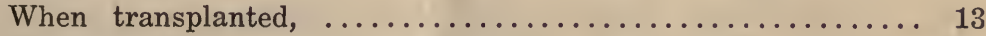

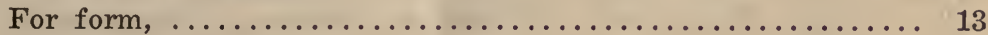

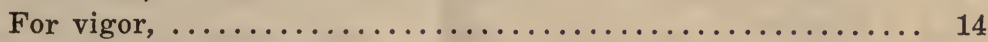

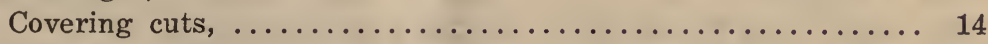

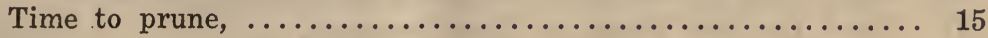

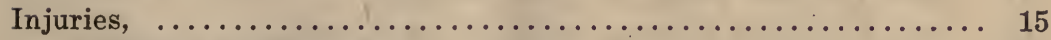

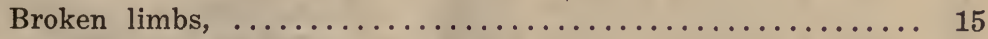

Frost cracks, sun cracks, and winter kill,............. 16

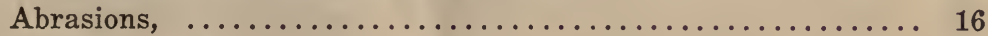

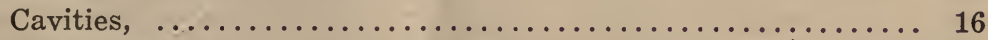

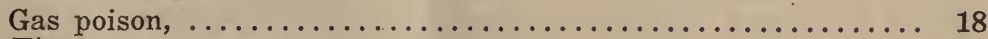

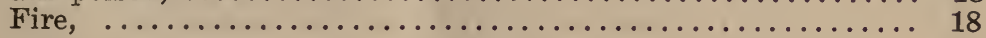

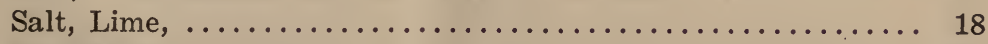

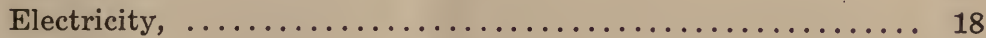

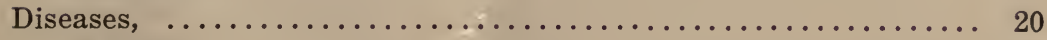

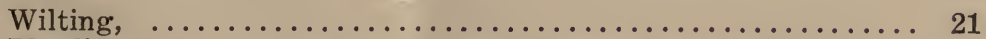

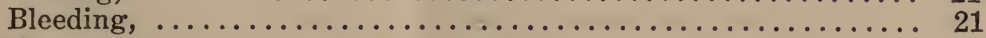

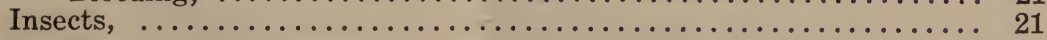

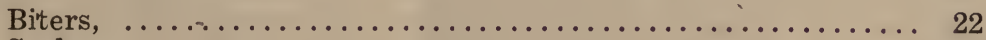

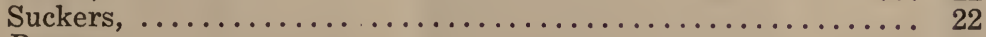

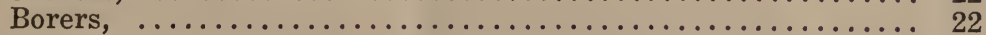




\section{Illustrations.}

FIGURE

- PAGE

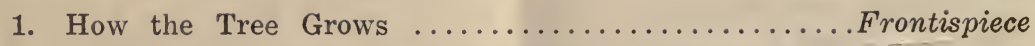

2. Young Trees Planted in Anticipation of Removal of Old-Trees.. 6

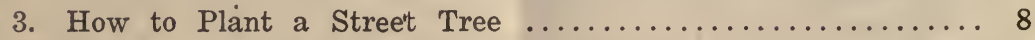

4. A Young Street Tree Failing thru Lack of Care.......... 9

5. A Young Street Tree Properly Planted and Well Cared For... 9

6. Use of Trees as Anchors for Guy Wires ............... 10

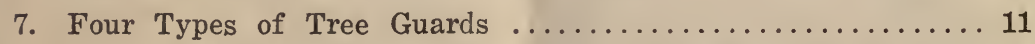

8. Norway Maple Showing Very Dense Crown ............ 14

9. Norway Maple with Superfluous Branches Removed by

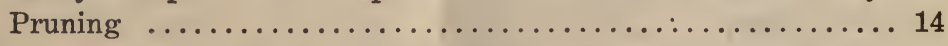

10. Right and Wrong Ways of Treating Wounds .......... 15

11. The Right and Wrong of Tree Doctoring .............. 17

12. Trees Butchered to Make Room for High Wires............ 19

13. Trees with Crowns Saved and Wires Carried on Low Poles..... 20 


\section{A Shade Tree Guide}

This bulletin will be helpful to municipal authorities and to those who wish to maintain vigorous, attractive trees on their properties. Few people realize that any tree standing beside a sidewalk, or even on a lawn, is out of its element (the forest), and that the strains and dangers to which it is subject must be counteracted in every way possible. The advice given refers particularly to New Jersey; it is applicable to most of the eastern United States.

The value of shade trees. Tho it is now well established that a shade tree has a value beyond that of its wood, or the cost of planting a new one, and that neither individuals nor public service agencies can injure one without becoming liable for damages, it is advisable always to avoid such troubles.

Street trees and lawn trees. It is needful to distinguish between street trees and lawn trees because only a few deciduous species, and no evergreens, can be maintained on narrow paved ways, whereas a lawn admits a variety of trees and shrubs, deciduous and evergreen, that is limited only by space and climatic conditions. On streets and lawns close to the sea the available kinds of trees are few, and extreme care in their selection and nurture is required.

\section{Street Trees}

Shade Tree Commission. It is always advisable to have street trees under the control of a Shade Tree Commission, such as is maintained in many communities in New Jersey and in several other states. These organizations can secure better results than individuals.

Old trees. An established tree, even of poor kind, is better than a newly planted one. Unless an old tree is decrepit or a nuisance it should be saved until a new one can be started to take its place. If young trees are planted between old ones before the latter have to be removed there will be less objection to taking away the undesirable ones than there may be if gaps are created. (Fig. 2.)

What to plant. In the choice of trees for street planting there is no room for experiments; one must select a kind that will live, and give satisfaction, for many years under fixed, and usually unfavorable, conditions. It is generally agreed that an acceptable street tree must be of form suited to the space, hardy and not subject to insects or disease, fairly rapid in growth, a good shade producer, and neat in that it drops no objectionable litter. The list of available trees is practically limited to the following. In most cases choice should be restricted to the kinds indicated by italic type. 


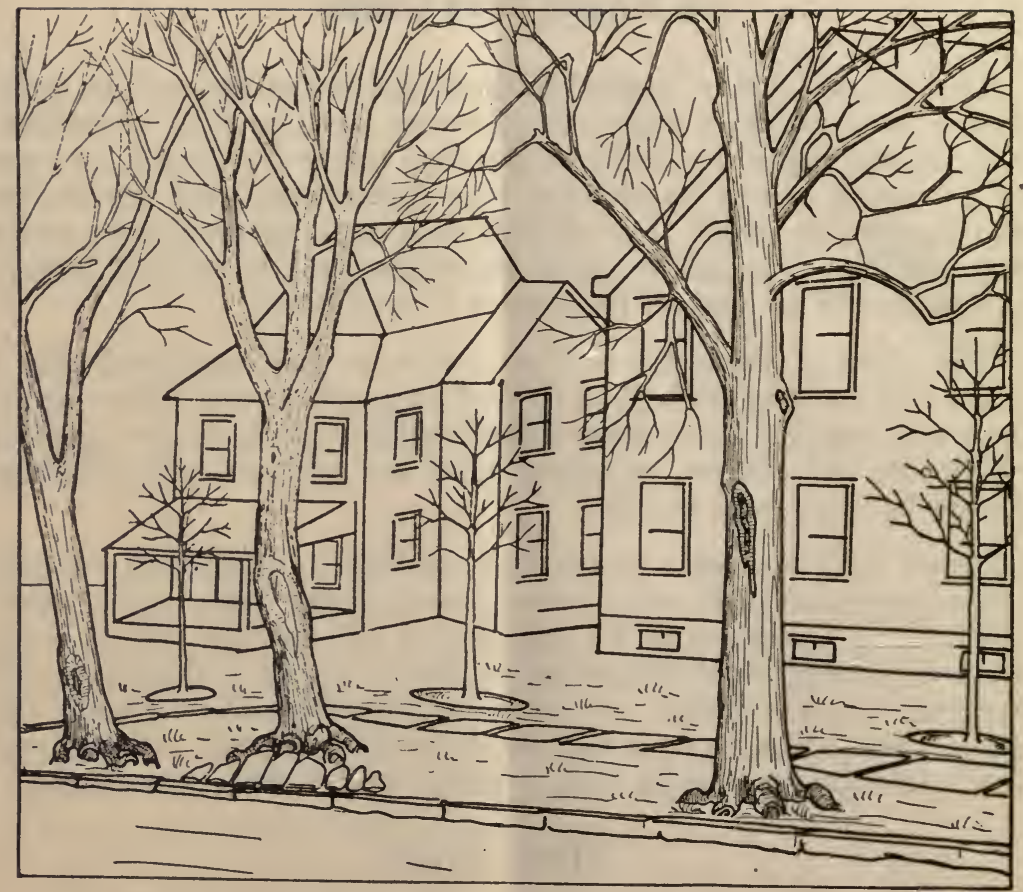

Fig. 2. Young Trees Planted on an Inside Line in Anticipation of the Removal of Decadent Old Trees on the Curbing.

The Best Trees for City Streets

\begin{tabular}{|c|c|c|}
\hline $\begin{array}{l}\text { Narrow Streets. } \\
\text { (less than } 60 \text { feet } \\
\text { wide between building } \\
\text { lines.) }\end{array}$ & $\begin{array}{l}\text { Average Streets. } \\
(60 \text { to } 90 \text { feet wide } \\
\text { between b u ild ing } \\
\text { lines.) }\end{array}$ & $\begin{array}{l}\text { Wide Streets. } \\
\text { (over } 90 \text { feet wide be } \\
\text { tween building lines. }\end{array}$ \\
\hline $\begin{array}{l}\text { Ginkgo } \\
\text { Norway Maple } \\
\text { Hackberry } \\
\text { Green Ash } \\
\text { Red Gum } \\
\text { Red Maple } \\
\text { Honey Locust }\end{array}$ & $\begin{array}{l}\text { Scarlet Oak } \\
\text { Ginkgo } \\
\text { Norway Maple } \\
\text { Red Oak } \\
\text { Sycamore } \\
\text { Hackberry } \\
\text { Red Maple } \\
\text { Pin Oak } \\
\text { Basswood } \\
\text { White Ash } \\
\text { Red Gum } \\
\text { Sugar Maple } \\
\text { Honey Locust } \\
\text { Horse Chestnut }\end{array}$ & $\begin{array}{l}\text { White Elm } \\
\text { Red Oak } \\
\text { Sycamore } \\
\text { Tulip Poplar } \\
\text { Sugar Maple } \\
\text { White Oak } \\
\text { Basswood } \\
\text { Red Gum } \\
\text { Scarlet Oak } \\
\text { Ailanthus }\end{array}$ \\
\hline
\end{tabular}


The tree to be planted will be more likely to thrive if it comes from a reputable nursery than if it grew wild, because nursery culture induces the development of compact root systems and lessens the risk of moving. The larger the mass of small feeding roots that is taken up, and the more earth that is moved with them, the quicker and better will the tree establish itself. Red Gum has very tender roots and is rarely planted successfully unless it is moved with a "ball" the same as an evergreen (p. Io). A tree of any kind should be healthy, symmetrical, and, as a rule, have a breast-high diameter of between 2 and 3 inches and a height of about 12 feet.

To insure the necessary headroom for street traffic no tree that forks at less than Io feet above the ground should be used, and no branch whose base is less than 7 feet above the pavement should be retained. Contrary to a common belief, the branches of a tree remain fixed forever at one height above the ground; their bases are not carried upward by growth. (Frontispiece.)

Trees to avoid. Silver Maples, Poplars and Willows are rapid growers but short lived, easily broken and given to producing surface roots and suckers. Locust is thin foliaged and subject to a boring insect. Nut trees invite injury by their fruit.

Location. If conditions permit it, trees usually should be planted inside the sidewalk rather than close to the curb. There they are less subject to injury, their roots have more room, their crowns are less in contact with overhead wires, and they shade the houses better. Wherever space permits it is well to depart from straight lines.

Intervals. Street trees usually are planted too closely together. The proper distance will be determined to some extent by the species, the width of the sidewalk and the front width of the building lots. A safe rule is so to space the trees that their crowns will never interfere, but have considerable air and light between. Thirty feet is a minimum interval; fifty feet or more is better.

When to plant. Trees can be planted at any time when they are not in leaf. They are most apt to succeed if planted in spring, as snon as the frost is out of the ground. A cloudy, quiet day is better than a bright or windy one. (See p. Io.)

How to plant. Dig the hole before the tree arrives and follow instructions given in figure 3 . If the local soil is poor make the hole at least two feet larger and one foot deeper than is required. Remove the poor soil and bring good, rich loam. Cut off all broken roots but save as many as possible of the small fibrous ones. Be careful that the roots do not dry out. Put enriched earth in the hole until the tree when standing upon it will be two inches lower, not more, than it stood in the nursery. Hold the tree upright, fill in the mixed soil and fertilizer and compact it firmly about the roots. 
Use plenty of water to settle the earth and be sure that every root is firmly embedded. Many newly planted trees die because their roots are left in air pockets. When all is done rake the surface to check evaporation. Successful tree planting depends upon care at every point-a vigorous tree with plenty of good roots, an ample bed of good soil for root growth and careful planting are of prime importance. Then frequent watering, occasional cultivating, and fertilizer once a year. If these things are ignored a tree may live but will never thrive.

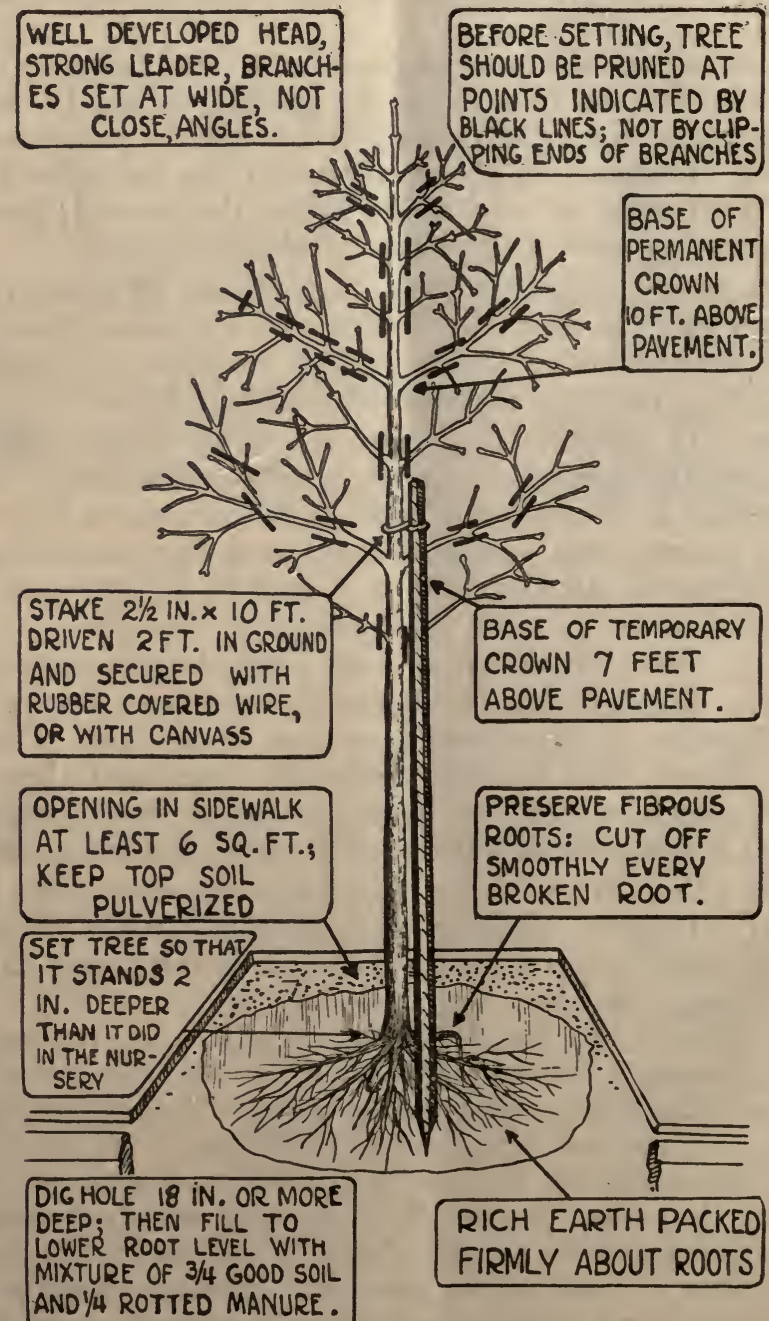

Fig. 3. How to Plant a Street Tree. It is Important to Observe Every Point Indicated in the Diagram. 
How to keep trees healthy. Any tree will resist insects and disease, and will recover from injury much more readily if it is vigorous and healthy than if it is weak. Observe the following rules: Never let a sidewalk be laid closely about a tree; a surface of bare earth (footing) at least 2 by 3 feet, preferably 4 by 8 feet, should be kept (figs. $2,3,5$ ) ; when a tree is fully established this may be grassed over, tho it is advisable to keep it open. Once a year work a little fertilizer into this open space and water it at intervals as directed at page $\mathbf{I} 3$.

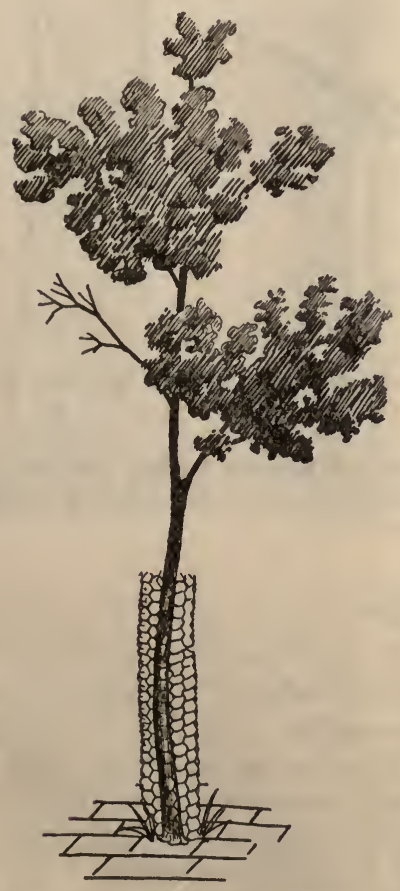

Fig. 4. A Young Street Tree. Failing Thru Lack of Care.-Of Poor Form, with Branches too Low, It is Crowded in a Brick Pavement, Has no Stake and Only a Short, Frail Guard.

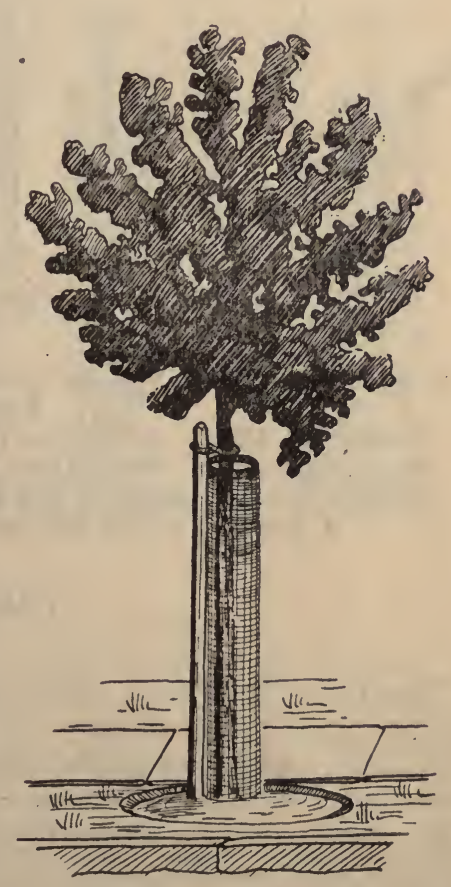

Fig. 5. A Young Street Tree of Good Form, Properly Planted and Well Cared For.-Guard, Stake, Footing as They Should Be.

If a young tree is exposed to winds or other strain, keep it firm and upright by means of a stout stake to which the stem is secured in such fashion that it will not be rubbed (fig. 5). Unless the tree is so placed that it cannot be gnawed by horses maintain a stout 
guard about it (figs. 5, 7). Apart from the pruning required when a tree is planted most trees should be allowed to develop naturally. Pruning as frequently practiced in butchery. (See p. I9 and fig. 12.) Allow no tree to support a guy wire except under necessity. In that case, and only if the tree is strong and healthy, let an eye bolt be driven into the heart, or all the way thru, and the guy wire attached to that; no form of band should be tolerated except temporarily in an emergency.

A

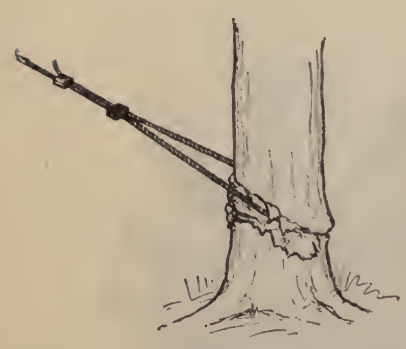

B

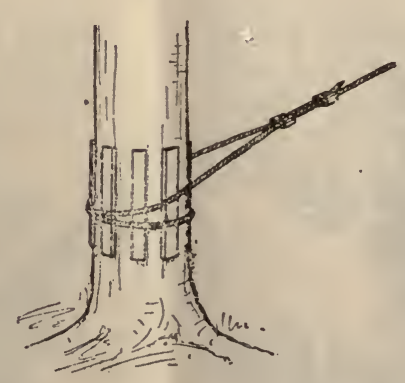

C

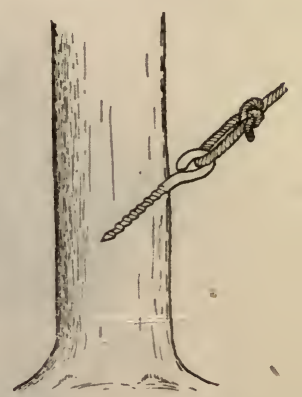

Fig. 6. Trees Should Not Be Used to Anchor Guy Wires Except in an Emergency.

A-Never Attach a Guy in This Way.

B-A Temporary Guy Should Have Wood Blocks Under the Wire.

C_If a Tree is Sound, a Lag Screw Driven Into the Heart Will Hold a Guy Wire and Do Least Harm.

\section{Lawn Trees}

Planting. Any tree with ample space about it requires only to be secured against injury and to be supplied with food and water. Deciduous trees should be planted exactly as recommended for street trees except that stakes and guards are rarely required. Evergreen trees, and a few deciduous species with succulent roots, as Red Gum, must invariably be moved from the nursery with the roots embedded in a ball of earth. When the hole has been prepared and good earth supplied, loosen the bagging that encloses the ball and set the tree with the earth still about its roots.

As a rule lawn trees, like street trees, do best when planted in early spring, tho evergreens allow greater latitude and often thrive when moved in August. When that is done it is important to guard them against strong winds in winter.

Lawn trees ordinarily require less care than street trees, but a circle at least 3 feet in diameter should be kept without sod about the base of a newly planted tree of whatever kind, and the soil within it worked frequently, until the tree is firmly established. Grass 
may then be allowed to grow, altho it is advisable to maintain the opening continually as a guard against injuring the base of the tree by the lawn mower.

"Wells" and mounds. If the level of the ground about an old tree is changed a "well" must be built in a fill to keep the soil away from the trunk and to avoid smothering the roots, or a mound left on a cut to prevent exposure.

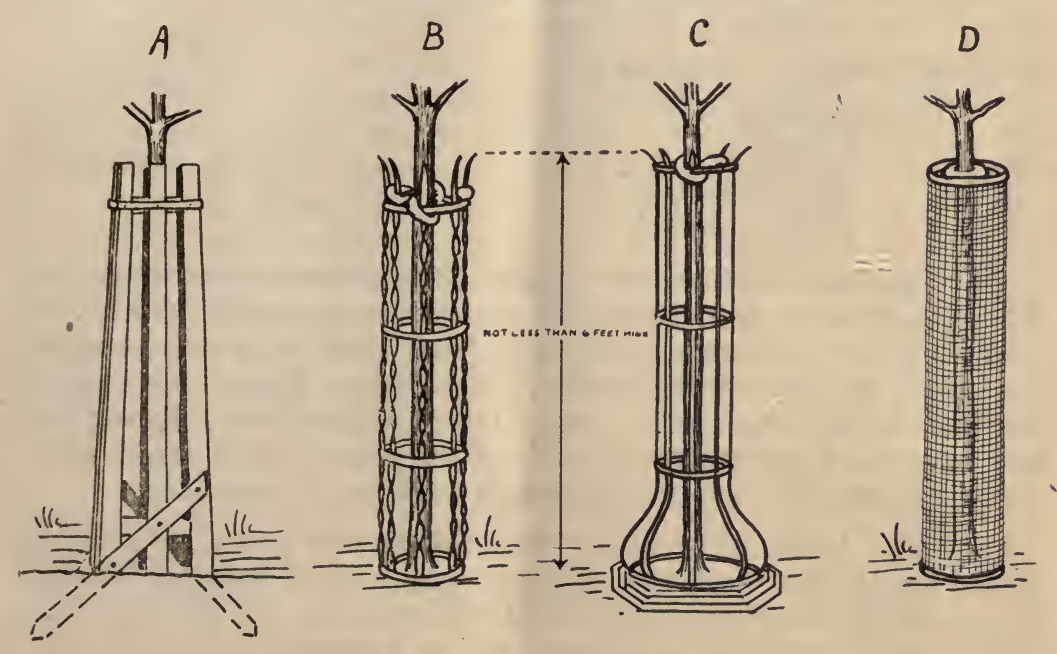

Fig. 7. Four Types of Tree Guards.

A-Standard in Washington, D. C. Made of Wood and Very Strong. It Also Serves as a Support, but is Unsightly and Not Cleanly. Cost About $\$ 1.50$.

B-Made of Ornamental Fence Wire. Too Frail to be of Much Value as a Guard and of None as a Support. Cost About $\$ 1.00$.

C_-Made of Heavy Wrought Iron. Is Attractive, Strong and Durable. Cost With Grill About $\$ 10$.

D_-Made of 1-2 inch Galvanized Iron Screen, with Rubber Hose Buffer at Top. Harbors Insects and Must be Supplemented by a Supporting Stake, but Very Popular. Cost About 80 Cents.

\section{Seashore Trees}

Whether along the streets or upon lawns, trees near the ocean have to contend with poverty of soil, deficient soil moisture and strong winds, those of winter in particular. It is useless to try to maintain trees where they can be reached by ocean spray-say within 200 feet of high water. Beyond that point it is simply a question of choosing hardy species and strengthening sterile soil. 
Fertilizer. It is not necessary to transport inland soil, the poorest sand may be treated thus:

Add to the native soil:

Oyster shell lime

Wood ashes

Composted (not fresh) manure

9 pounds

Or as a substitute for the manure, not in addition,

$A$ mixed fertilizer composed of:

2 parts tankage

2 " ground fish

3 " acid phosphate

3 " muriate potash

$2 \frac{1}{2}$ pounds

The quantities named are enough for 100 square feet of ground. As root spread is assumed to be equal to crown spread, a tree with a crown 6 feet in diameter will have roots covering about 30 square feet and will require three-tenths of the above. Do not use more or the trees will be injured. Apply the fertilizer every spring; the lime and wood ashes every three or four years. As a sandy soil is always porous frequent and abundant watering is necessary.

Support. Until it is firmly established every tree exposed to strong winds must be firmly supported by a stout stake or by three or four wires secured to pegs firmly driven into the ground. This is even more important in winter than in summer.

What to plant. For street planting the choice of species should be limited to sycamore, ailanthus, pin oak, scarlet oak, red oak, hackberry, honey locust, red maple, and in most situations preference given in the order named, altho it is not advisable that too many of the same kind be used. Upon lawns oaks and pines, with various hardy shrubs, are to be preferred to the firs, spruces and cypresses, and the many deciduous trees, that are available inland.

\section{Nourishment}

More trees suffer from starvation than from anything else. On lawns as on sidewalks a tree's natural food (fallen leaves, etc.), is taken away, water is denied and both rain and air are excluded by close pavements, or by sod. The consequent weakened condition induces disease and insect attack. Don't plant a tree unless it can have at least 6 square feet of open soil at its base. For several years after a tree is planted this is imperative, afterwards sod, not paving, may be tolerated. Frequent working of the surface soil, as in any garden, will tend to keep a tree in good condition. 
Water. Street trees require more water than lawn trees because their roots are apt to be restricted and because sun-heated pavements and buildings increase transpiration. A good rule is to see that the ground about a tree is soaked once a week. If rain fails use the hose or a pail. Sprinkling, tho done frequently, is only a little better than nothing. Too frequent soaking will exclude the air and cause the roots to rot. When the ground has dried after a wetting, rake the surface to check evaporation. If the ground does not dry within an hour too much water has been applied.

Food. In the forest, and in neglected places, nature provides trees with food. Along the streets and on well-kept lawns it mùst be furnished. If a tree shows thin foliage, slender branches or a dead top starvation may be suspected. The best fertilizer is composted (not fresh) manure. In the spring spread it 2 inches deep over as much of the root extension as can be reached and fork it into the soil; or, tho not so good, put it on December first and let it lie over winter, when what remains can be raked off. On a paved street the fertilizer must be placed in the opening at the tree base, but whenever possible it should be spread away from the trunk and beneath the foliage, where most of the feeding roots are found. If manure is objectionable, apply each spring $I^{1 / 2}$ pounds per IoO square feet of a commercial fertilizer composed as follows:

Nitrate soda

Acid phosphate

Muriate potash ${ }^{1}$

Ground bone

\section{For light soils.}

$\begin{array}{ll}\text { I } & \text { part } \\ \text { I } & \text { I } \\ \text { I } & \text { " }\end{array}$

For heavy soils.

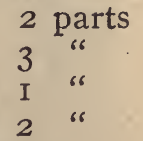

Distribute the fertilizer evenly and mix it with the soil; be careful not to use an excess else the tree roots may be burned.

If it is desired simply to sustain an old tree without inducing growth, use a small quantity of manure, or from $I$ to $I \frac{1}{2}$ pounds per IOo square feet of a mixture containing I part nitrate soda, I part bone meal, 5 parts acid phosphate.

\section{Pruning}

Trees need to be pruned only (I) when they are transplanted; (2) when they interfere with other trees or structures; (3) when they are weakened by decay or by overgrowth. Much of the pruning done by so-called experts is useless or even harmful. Most trees should be allowed to develop according to their natural habit. When pruning is permissible the following rules apply.

When transplanted, a tree must have its crown cut back to balance the inevitable loss of roots. See figure 3 , and observe that useless interior branches are removed entirely.

Form. If a tree grows one sided, if its branches interfere with a building, or with another tree, curtail or cut out entirely the aggres-

${ }^{1}$ Wood ashes may be substituted at the rate of 10 pounds to 1 pound of muriate potash. 
sive member. With few exceptions trimming the ends of branches is wrong and cutting off the whole top is butchery.

Branches which hang too low should not be trimmed, but cut back to the trunk or main branch. If branches grow so that they interfere with electric wires, either have the wires lowered, or remove entirely all but the three or four most vigorous shoots and stimulate the tree to carry a crown above the wires. (See p. 19.) For treatment of heavy limbs see Injuries, page I 5 .

Vigor. If a tree is so weakened that dry branches appear, cut out all the dead wood, and such of the living members as is necessary to make the tree shapely. If lack of vigor is shown by drooping foliage and the crown is very dense (as is common in Norway maples and sugar maples), relief will be given by removing a quarter or a third of the foliage. This should be done, not by cutting off the extremities, but by taking out interior branches entire (figs. 8, 9). When done skilfully the appearance of a tree as well as its strength is improved. After pruning for vigor a tree should always be well fertilized and watered.

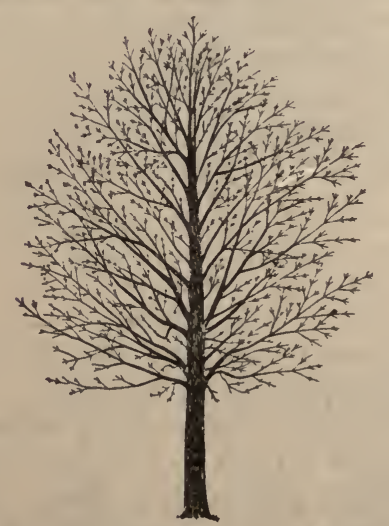

Fig. 8. Diagram, from a Photograph, of a Norway Maple Showing the very Dense Crown Common with this Species. The Foliage Produced Makes a Heavy Draft upon the Soil Fertility and Water and Frequently Leads to Wilting.

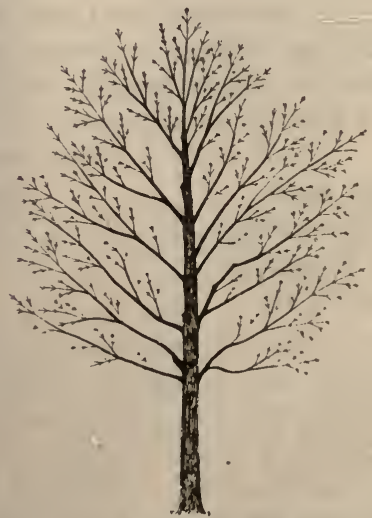

Fig. 9. The Same Norway Maple as that Shown in Fig. 8 with Superfluous Branches Removed by an Interior Pruning. This Preserves the Natural Form of the Crown and a Frame that will Produce as much Foliage as is Desirable.

Covering cuts. Unless it is properly treated every break in the bark of a tree affords entrance to disease germs. In practice clean cuts less than an inch in diameter are ignored; every larger wound should be coated with an antiseptic. The most practical is creosote followed by coal tar. Tar alone is often used, but does not penetrate deep enough to give best results. Creosote is a dark oil and can be applied with a brush. Tar should be made liquid by heat and applied in the same way. It is advisable to avoid covering the cambium. 
Time to prune. Pruning may be done when it is most convenient unless "bleeding" (p. 2I) is induced. That is most apt to occur in early spring or early fall. Late winter is usually best because there is then little sap movement and the absence of foliage makes the work easier. (See p. 8.)

\section{Injuries}

Broken limbs. Every broken limb should be cleared away promptly by a cut, or succession of cuts, that leave a wound which will heal quickly. Small limbs can be taken off by a single cut, larger ones require three, as indicated at B, figure II. It is important to use a sharp saw, make the final cut close to the larger member and be careful that the bark at the bottom is not torn. A wound shaped as indicated at RIGHT, figure IO, will heal most quickly; one shaped as indicated at WRONG will heal more slowly at the top because the arch is flatter, and very slowly at the bottom because the bark is torn away. A stub as at C, figure II, should never be left. The face of the wound should be treated as directed on page 14. Cement will do harm rather than good.

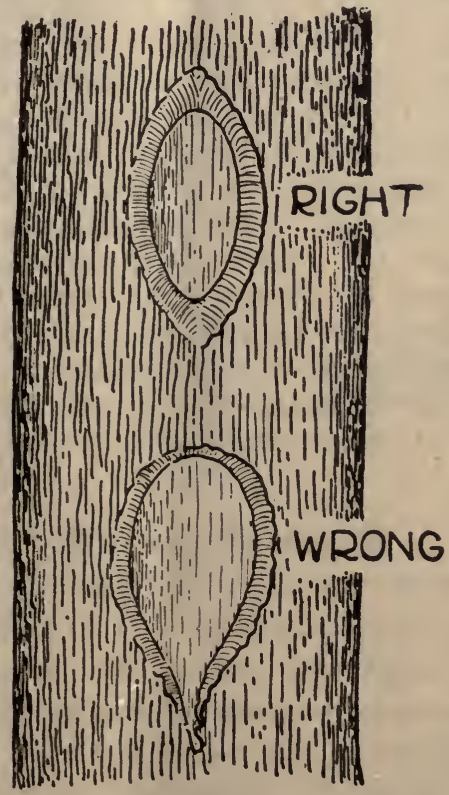

Fig. 10. Cut Marked RIGHT is Healing Properly and Quickly. Cut Marked WRONG is Healing Slowly, and Not at All at the Bottom, Where the Bark is Torn. Every Wound on a Tree that Can be so Treated, Whether a Mere Bark Bruise or the Stub of a Severed Limb, Should be Trimmed to a Long, Regular Oval. 
Frost cracks, sun cracks, and winter kill. Extremely cold weather, especially when it follows a late growing season, sometimes freezes the water in the outer cells of a tree stem and causes a long crack. Thin-barked species, like sycamore and horse chestnut, are most susceptible and any tree on a street, exposed as it must be, is apt to suffer. Sun cracks have the same appearance but are caused by excessive heat, often reflected from a white pavement or wall. In large trees such cracks usually close again with warmer weather and no serious harm is done, but the wood does not unite and a scar is left. On small trees the crack is apt to persist until new growth covers it. There is no practical preventive, and no remedy other than helping nature by every care to heal the wound. This can be hastened by treating the crack with antiseptic, and keeping it from reopening by strong staples, driven in warm weather when the gap is narrowest. "Winter kill" occurs when the vital parts of a tree trunk are frozen and ruptured in a horizontal plane by the formation of ice about its base. There is no remedy, but the trouble can usually be avoided by having the ground slope away from the foot of a tree on all sides so that no water can collect there. "Winter kill" is common on the terminal shoots of many trees and shrubs and rarely does permanent harm.

Abrasions. Surface wounds, made by horses, lawn mowers, blows, etc., are the starting places of most of the decay that destroys shade trees. It is little realized that many serious tree wounds originate between the nursery and the planting site. If the trunk of a young tree is thrown on the side-board of a wagon the tender bark and cambium are apt to be crushed, and tho the injury may not show at the time the growth of the surrounding parts reveals it. Every care should be taken to avoid these injuries. When one occurs let the injured part be cut out carefully with a sharp knife or chisel until sound wood is exposed and the edges left smooth. Then sterilize and tar the wood-not the cambium or bark, and leave the rest to nature. Cement should not be used. (See F and H, fig. II.)

Cavities. Cavities in trees are invariably the result of decay. They are treated with one or all of three objects in view: (I) to stop the decay and induce healing; (2) to hide an unsightly part; (3) to support a weakened body. The belief that every cavity should be filled is wrong, because, even with the best workmanship, a filling merely retards decay, it does not stop it. The best rule is to clean a cavity thoroly-cutting out all decayed tissue with a gouge and mallet until sound heart wood is exposed. If the cavity will not hold rain water, or the wound is not unsightly, trim the edges neatly, treat the wood surface and stop. 


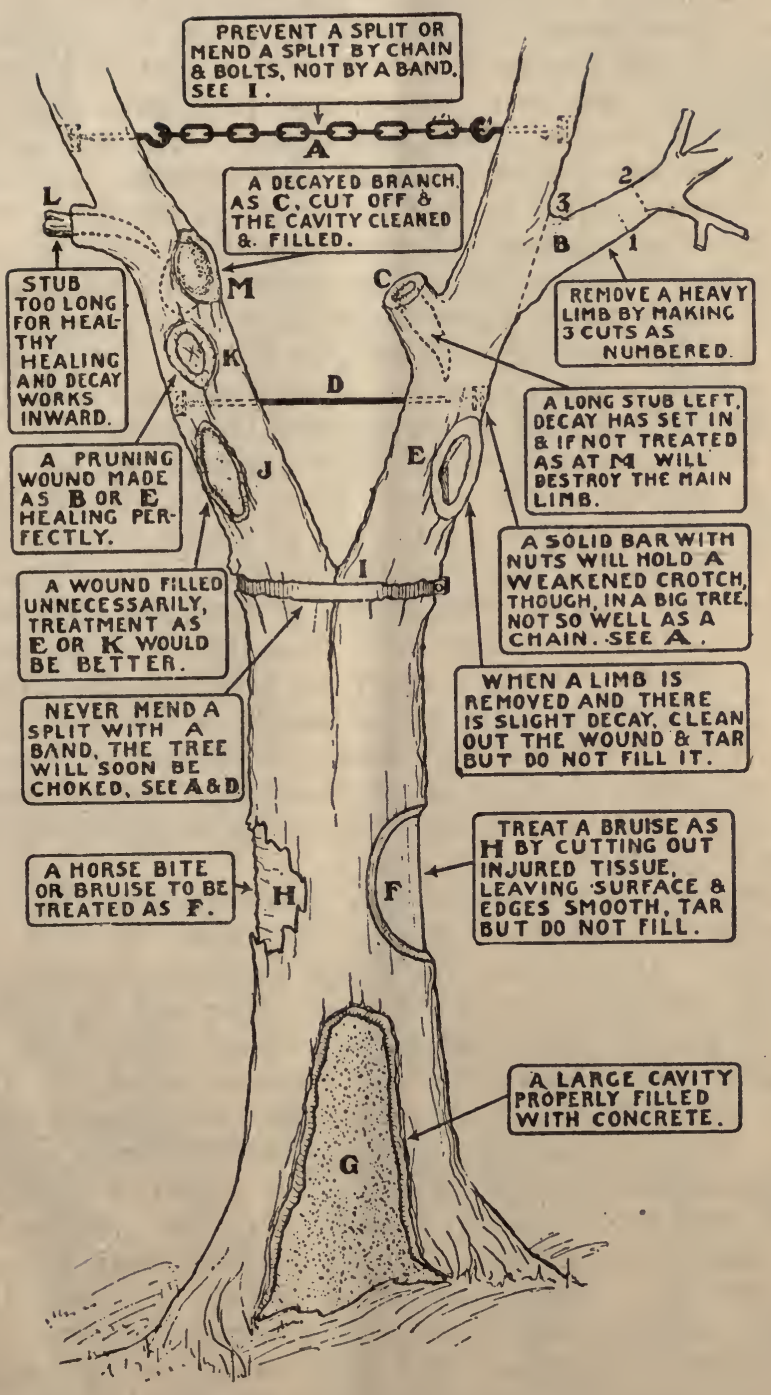

Fig. 11.-The Right and Wrong of Tree Doctoring.

If the cavity cannot be drained, if it is unsightly, or if the tree needs support, a concrete filling may be placed. Before doing this any but a pocket cavity should be shaped so that moisture will drain from it, and set with nails or wires to hold the concrete in place.

In many cases it is advisable simply to clean the cavity, and, 
without attempting to fill it, cover the opening with cement, sheetmetal, or wood blocks (creosoted), to guide the growing callus. For small cavities a mixture of half cement and half sand is best; for larger ones one part cement, one part sand and two parts gravel, broken stone or cinder will answer. The surface of a filling may be smoothed with a coat of clear cement. The sand, stone or cinder should always be free from dirt of any kind, the cement thoroly mixed and as soft as it can be handled.

Gas poison. If illuminating gas escapes from a faulty pipe into the soil in which a tree grows the roots may be poisoned, cease to function and the tree be weakened or killed. The extent of the damage, and the rapidity of action, depend upon the quantity of gas, the porosity and moisture of the soil, and the character of the pavement or other ground cover. A little gas may find its way to the air and do no great harm; a large quantity can kill in a day every tree whose root system it penetrates. If a tree is killed while it is leafless, it may give no sign until the following spring when its foliage fails to come out, or, coming out, is weak and soon falls. The only sure test for gas is the odor. If a leak is suspected make a hole with a crowbar or auger about two feet from the tree and two or three feet deep and apply one's nostrils to the opening. If gas is indicated the leak must be found and stopped at once. Sometimes a tree subjected to gas can be saved by trenching about it and watering the soil freely, but most cases are hopeless unless only a little gas has escaped.

Fire must not touch a valued tree. Even the slight heat given off by a burning leaf pile may cause serious injury.

Salt, lime. Many trees are killed by having brine from icecream tubs, or from salt used to melt pavement ice, penetrate to their roots, and some are lost by an excess of lime water washed from nearby mortar beds. Preventive measures only are effective.

Electricity. Ordinary electric currents never injure the vitality of a tree, and wires carrying a high potential current which might do damage, especially in wet weather, are bound to be properly insulated to save loss of power. The injury that trees suffer from electric wires is invariably a cutting or local burning caused by friction between a loose wire and a branch, or, more often, the mutilations performed by careless or ignorant linemen. The rules of the electric companies forbid their employees to use any tree without the consent of the owner and provide for expert supervision of any tree trimming that is authorized. Linemen frequently ignore these rules, but no tree need suffer if its owner will take the trouble to report the case to headquarters before the damage is done. In many cases the company will completely trim and fix up a tree for the privilege of carrying their wires thru it. In this State an owner should always be represented by a Shade Tree Commission. 


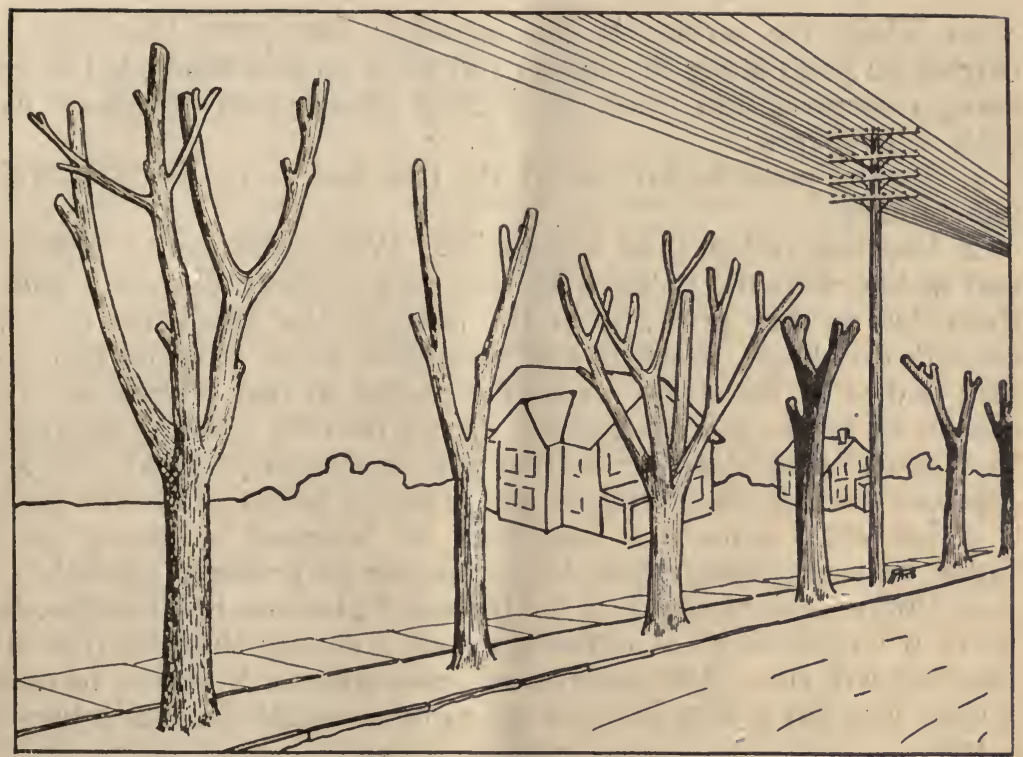

Fig. 12. A Row of Old Trees Butchered to Make Room for High Wires. Compare With Fig. 13.

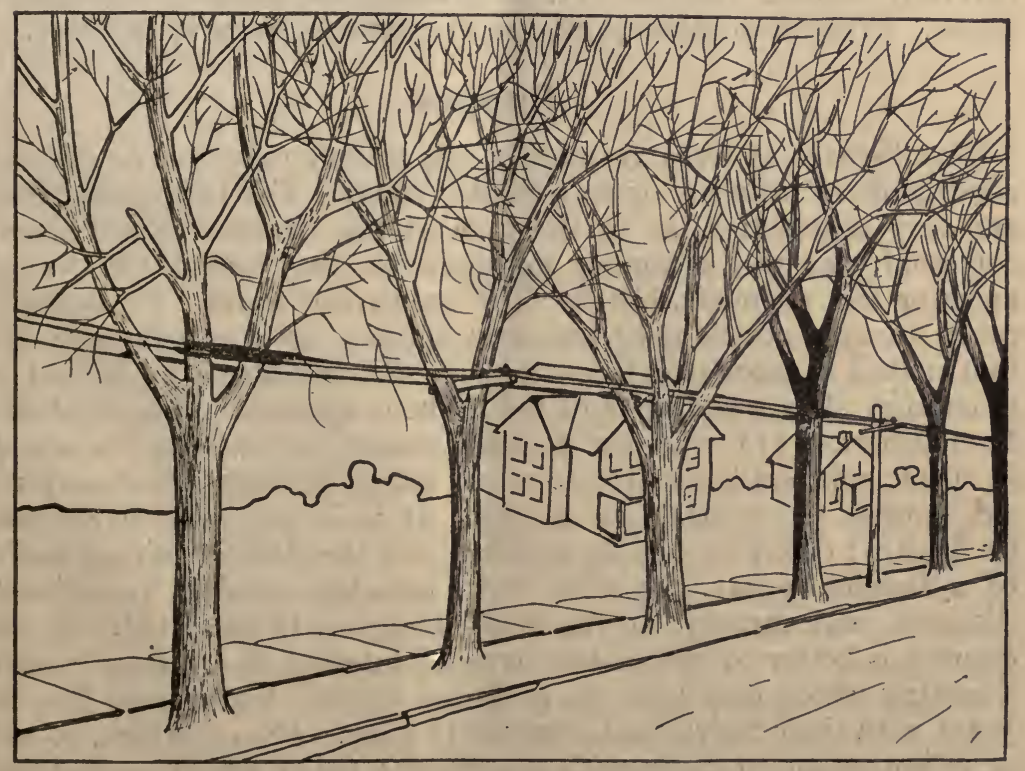

Fig. 13. The Same Trees as in Fig. 12, With Crowns Saved and Wires Carried Thru Them in Cables on Low Poles.

The construction of electric lines is a necessity of our civilization; the cost of carrying the wires underground is prohibitive except in 
cities where the service is concentrated; they must therefore be carried on poles along the streets and must be accommodated to existing structures and trees. In making these accommodations five rules will govern:

I. Set the poles as far out of the tree line as possible, to avoid interference.

2. Use low rather than high poles. Where the trees are small, and in line with the poles, it is necessary to carry the wires above them, but as they grow, lower the poles so that the wires may be carried, on offsets, brackets and insulators, away from or thru the firm bodies of the trees. A wire fastened so that it does not rub can do no harm; a bolt carefully driven into the heart of a branch to support an insulator or a cross arm is always justified; but any vigorous tree will soon outgrow the practical height of electric poles.

3. Let cross arms and insulators be fastened to strong trees, rather than set poles, where the wires can be properly carried.

4. Provide guard strips on the trees and abrasion moulding on the wires wherever there is movement and a chance that the tree and the wire will rub. The removal of small interior branches to make a clear way for a wire is more apt to be a benefit than an injury to a tree.

5. Have all cuts larger than I inch diameter made smooth and carefully treated (see p. I4), to prevent the entrance of disease germs. Prohibit absolutely the use of climbing spurs in any tree.

\section{Diseases}

The diseases of trees are chiefly due to abnormal soil or climatic conditions, to injuries, or to parasitic fungi. The latter sometimes are very destructive, as in the case of the chestnut blight; more commonly, as the sycamore anthracnose, they affect the foliage more or less seriously, but do little permanent harm. Fortunately, most diseases attack only one tree species, or one genus, - a law that makes diagnosis and control less difficult than they would be otherwise. If a tree begins to fail without apparent cause, it should be questioned (I) whether it lacks water; (2) whether it stands in sterile soil and lacks fertilizer. If either deficiency is discovered the remedy is obvious (see p. I3). If it is not, a specialist may be helpful; often he can do nothing. If the fleshy fruiting bodies of a fungus appear, the tree, or its affected member, is seriously diseased, and surgery, or the tree's removal, is indicated. It frequently is better to ignore the signs of internal decay than to start a cutting which may have no practical limits. Many trees live for years with their heartwood completely gone. (See Cavities, p. I6). It is important to distinguish the fungus fruits which appear only on dead wood, from those which are parasitic. A special publication, "Common Diseases of Shade Trees," can be obtained upon request of the State Agricultural Experiment Station, New Brunswick. 
Wilting. The leaves of shade trees frequently wilt out of season. Sycamores are apt to lose their first leaves in the spring from a prevalent disease, but soon get a second set and usually suffer little permanently. No specific treatment is advised. Other species, especially maples, are beset with lice or scale insects which by sucking their juices cause the leaves to die. If the attack is slight let nature take care of it ; if it is serious spray as directed on page 22. But most trouble of this kind is found in Norway and sugar maples; the cause is obscure, yet there is reason to believe that too little food, sometimes too little water, is available to nourish the heavy leafage that these trees produce. Feeding and watering (p. I3) will usually prevent this trouble; if it develops, let the foliage of the affected tree be curtailed by an interior pruning ( $p$. I4), then fertilize. (Figs. 8, 9.)

Bleeding. This frequently occurs when branches are cut while the sap is moving freely. Under such conditions stop all pruning as loss of sap lowers the vitality of a tree.

Another sort of bleeding, sometimes called "slime-flux," and having an offensive odor, usually begins in a wound, or behind a filling, and is often hard to manage. Like a sore in the flesh the worst possible course is to stop it from the outside; it must be cleansed, sterilized and made to heal from the inside. Let all affected tissue -bark and wood, be cut out with a sharp chisel, the wound pointed at top and bottom (fig. Io) and all edges left smooth: sterilize the exposed surfaces with weak formalin and cover with tar; never use cement. If the trouble is due to a split crotch, clean the crack as well as possible, bolt the parts together, as at D, figure II, and treat as above.

\section{Insects}

Not all insects are harmful to trees: some, tho harmful, are so controlled by natural enemies that they rarely are found in numbers great enough to do serious damage; others attack only trees that have been weakened by neglect or injury.

As with diseases, harmful insects usually confine their attacks to trees of one species, or one genus. Thus the elm beetle attacks elms only, the hickory borer only hickories. It is entirely safe to - say that a few insects of any kind on a vigorous tree will do little harm; a few insects on a weak tree should be looked after, and many insects on any tree demand prompt attention. But to be always on the safe side every suspected case should be referred to some authority-an entomologist or a forester. Ants are rarely harmful; their presence about a tree usually means that honey dew, decayed wood or fungus growths are available for their food.

Injurious insects are grouped in three classes: biters, suckers, and borers. 
Biters. These commonly attack the foliage and may work as adults (beetles) or as larvæ (caterpillars or worms). Control is determined by a knowledge of the life history of each species, but a general remedy is to poison their food. The best means is to spray thoroly with arsenate of lead according to directions given on the commercial packages. Banding a tree trunk with cotton or some sticky stuff is useful only when the insects are crawling $u p$. Bag worms, tent caterpillars, etc., which form conspicuous shelters or colonies in tree crowns, and forms like tussock moths which set egg masses on nearby structures, as well as on the trees, can often be destroyed by hand or by fire even more successfully than by spraying.

Suckers. These appear as minute, crawling insects, frequently protected by woolly, waxy or scaly coverings. They locate on the younger branches, or on the leaves, often in enormous numbers, and live by sucking the sap. Some forms can be washed away with a strong jet of water from a hose, but in most severe cases thoro and repeated spraying with a caustic, or with a penetrating oil, is necessary. Fish-oil soap suds is good for the tenderer forms, especially when reinforced with tobacco extract; lime-sulfur or soluble oil is best for those with scaly armor.

Borers. Boring insects work, as beetles or worms, in the twigs or buds, in heartwood, or, most frequently, in the cambium layer between sapwood and bark. Their presence is indicated by broken branches and by small holes in the bark beneath which wood dust is often found. In our territory a few species attack healthy trees, but most seek out those whose vitality has been lowered. Control is difficult because the pest is mostly out of sight, and, tho help can sometimes be given, it usually is necessary to depend chiefly upon keeping the trees in good health. Against the locust borer anything else is useless. Any hickory tree that is seriously infested with the hickory borer is doomed and should be cut down and burned without delay for the sake of nearby trees, and the latter should be stimulated by feeding to ward off attack. Leopard-moth larvæ are especially fond of young, newly-planted street trees which are struggling to establish themselves. A measure of control is possible by cutting out the boring worms, by crushing them with a wire run into the burrows, by injecting carbon bisulfid, and especially by encouraging insect eating birds. More specific advice is given in a publication of the State Agricultural Experiment Station, New Brunswick, "Insect Enemies of Ornamental Trees and Shrubs," by Harry B. Weiss, which will be sent upon request. 


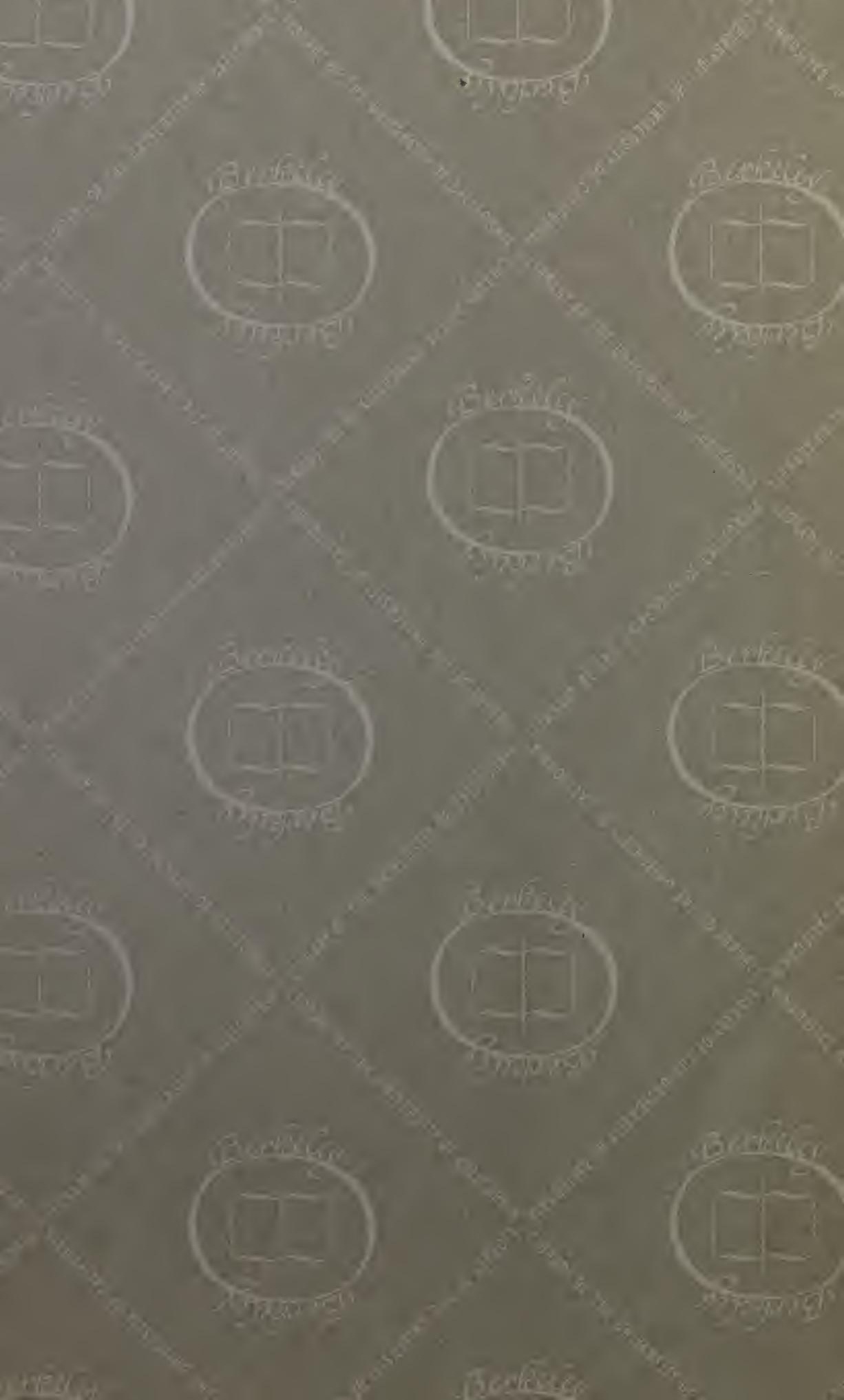


